\title{
Cross-Curricular Teaching in Foreign Language Classrooms of Jaen and Newcastle Secondary Schools
}

\author{
Diego Rascón Moreno \\ University of Jaen
}

Received: 20 November 2009 / Accepted: 11 May 2010

ISSN: 1697-7467

\begin{abstract}
At the end of the first term of the 2006-2007 academic year questionnaires were handed to compulsory secondary education students and teachers of English in the Spanish city of Jaén with a view to finding out about the teaching of the CrossCurricular Issues (CCIs). Then, one year later, the same surveys were handed to 8-11 year students and teachers of French or Spanish in the English city of Newcastle-uponTyne with the same purpose. The information obtained shows that the cross-curricular approach introduced in Spain in 1991 is more often followed in the contexts under research of Jaén than of Newcastle.

Keywords: Cross-Curricular Issues, Content and Language Integrated Learning (CLIL), education in values, Foreign Language Classroom and compulsory secondary education.

Enseñanza transversal en clases de lenguas extranjeras de institutos de Jaén y Newcastle

RESUMEN: Al final del primer trimestre del curso 2006-2007 se pasaron cuestionarios a alumnos y profesores de inglés de Educación Secundaria Obligatoria (ESO) de Jaén con la finalidad de saber acerca de la enseñanza de los Temas Transversales. Posteriormente, un año más tarde, se les realizaron las mismas encuestas a alumnos y profesores de francés o español en los años académicos 8-11 de la ciudad inglesa de Newcastleupon-Tyne con el mismo objetivo. La información obtenida muestra que el enfoque transversal introducido en España en 1991 se sigue más a menudo en los contextos investigados de Jaén que en los de Newcastle.

Palabras clave: Temas Transversales, aprendizaje integrado de lengua y contenido, educación en valores, clase de lengua extranjera y Educación Secundaria Obligatoria (ESO).
\end{abstract}

\section{INTRODUCTION}

The academic year 2006-2007 was the last one when the Ley Orgánica General del Sistema Educativo (LOGSE) curriculum for ESO was applicable in Jaén and the rest of Spain. This document stated that «moral and civic education», «peace education», «health education», «gender education», «environmental education», «sex education», «consumer education» and 
«road safety education» must be integrated in all subjects and throughout the whole of this four-year stage (Real Decreto 1345/1991: introducción). Therefore, the Foreign Language (FL) teacher (English being by far the most popular FL taught in Spanish schools) would have to make an effort to introduce this value-laden content in their classes.

On the other hand, 2007-2008 was the last academic year when the 2000 National Curriculum for Key Stages 3 and 4 was valid in Newcastle and all England. This document mentioned four general teaching requirements (inclusion, use of language, use of ICT, and health and safety), and that spiritual, moral, social and cultural development would be promoted across all subjects. However, it did not seem to advocate cross-curricular teaching as much as the LOGSE since it did not refer explicitly to the teaching of a series of CCIs, as the law in Spain did. Moreover, it incorporated the mandatory subject of Citizenship Education where issues of moral and civic kind could be specifically addressed.

\subsection{Objectives}

The main purpose of the research described in this paper is to know about the teaching of the cross-curricular topics mentioned in the LOGSE curriculum in FL classrooms of ESO in Jaén and of the equivalent years 8-11 in Newcastle. Namely, I intend to find out:

1. How often they are addressed according to students.

2. How often they are addressed according to teachers.

3. The techniques and resources that are used to cover them.

4. If these issues are assessed.

\subsection{Features}

The information collected was taken directly from students and teachers, so this research is primary. In terms of the approach followed, this study is also global as it is concerned with the teaching of the cross-curricular topics in general. Its method of collection is cross-sectional because the required information was obtained by many people and in a short period of time in each of the cities.

The data gathering, analysis and interpretation presented here are consistent as will hold good over time and another researcher remaking them would reach the same conclusions. Thus, this study can be claimed to be «internally reliable». It is also believed to be «externally reliable». However, this cannot be proved now because reproducing it in both cities would not happen in the same circumstances since cross-curricular teaching was given a different status in the new national curricula for the groups under investigation that came into force in Spain and England in the academic years 2007-2008 and 2008-2009, respectively (Nunan, 1992: 14).

On the other hand, information was collected from two different sources (students and teachers) and both questionnaires measured well what I purported to measure in relation to the CCIs. Some of the items in each of them were connected. This contributes to the «internal validity» of my research (op.cit: 14-15).

In addition, the results obtained from Jaén secondary schools are generalisable to the whole city since classes from most of the three kinds of existing institutions offering ESO were sampled and they were in similar proportion. They even may be generalisable to other cities 
or towns of the province and autonomous community with a related percentage of ESO FL teachers from each of the three kinds of school but this would be of less foundation. It would be more founded to assert that at least results from state high schools could be generalised to the whole of Andalusia as it has been observed that CCI teaching depends a lot on publisher materials (see figure 9) and all state schools in this region are supposed to have a similar budget and similar resources. Concerning results from the Newcastle schools sampled, they cannot be so easily generalised to the whole city because even if all kinds of schools are represented in the study, with the exception of the two technological colleges, they are not in similar proportion and the total percentage of all schools participating is not high (op.cit: 15).

\section{Methodology}

\subsection{The sample of subjects}

On the Spanish side, the study was carried out in 20 of the 23 secondary schools in the city of Jaén. 10 of them are state-maintained schools (out of the 12 existing ones) and the other 10 are schools with a Christian ethos, 8 of which are publicly funded (colegios concertados) (out of the 9 existing ones) and the other 2 are the private ones in the city that do not receive any state subsidy (colegios privados). 1306 students and 52 teachers took part in the research. The subjects investigated were students that had chosen English as their first FL and teachers of this language in any of the four years of ESO. Whole classes were sampled. All groups were mixed save for the 5 classes from the 2 private schools participating, 3 of which were constituted only of boys and the other 2 only of girls.

On the English side, the study was carried out in 9 of the 20 secondary schools in the city of Newcastle. 3 of them are state-maintained schools (out of the 9 existing ones), 3 of them are all the publicly funded schools in the city that have a Christian ethos and the other 3 are independent schools (out of the 6 existing ones). 536 students and 25 teachers of French or Spanish from year 8 to 11 participated. Whole classes were sampled. 15 groups were mixed, 6 were constituted only of girls and 4 only of boys.

In the schools where only one teacher was in charge of English in ESO, in the case of Jaén, and of French or Spanish in years 8-11, in the case of Newcastle, one class participated. Where there was more than one teacher in these levels, the research was conducted with a class taught by each of them. That is to say, the same number of classes participated as of teachers to which the questionnaires were handed (52 in Jaén and 25 in Newcastle). The groups were selected randomly but paying attention to obtaining information from an equivalent number of groups in each of the years under research from each of the types of schools participating.

Unfortunately, I could not count on the surveys given to 4 teachers in Jaén and 2 in Newcastle for different reasons, despite having sampled their classes. Therefore, 48 and 23 are in the end the amount of surveyed teachers in Jaén and Newcastle, respectively.

On the one hand, classes sampled in Jaén were of English as this is by far the most popular FL in its schools and my doctoral research is focused on English Language Teaching (ELT). On the other hand, the FL classes sampled in Newcastle were of French or Spanish 
because handing the questionnaires was supplemented with the analysis of the course contents (whose results and conclusions will not be provided here for space restrictions) and these are the FLs in its schools that I can read.

It should be mentioned that students sampled in the two cities are not supposed to have started learning the target language at the same time. While students in Jaén had to begin learning a FL four years before ESO (i.e. in the 3rd year of primary education), those in Newcastle did not need to do so before Key Stage 3 (year 7). Thus, it is reasonable to believe that, in general, students in Jaén had a better knowledge of the target language than their Newcastle counterparts at the time the research was conducted. All of them had from three to four weekly classes of the target language depending on the course.

Finally, it is also worth pointing out that while students in Jaén would be assessed summatively at the end of the academic year by their teachers, who could decide if they promoted or not to the next level (with the exception of the first year of ESO), students in Newcastle would more rarely fail promotion but those in year 9 would take National Curriculum Tests and those in year 11 the so-called General Certificate of Secondary Education (GCSE) exams at the end of the course.

\subsection{Instruments}

Quantitative data from students was collected by means of a structured questionnaire on $\mathrm{CCI}$ teaching that was intended to be very simple and easy for them to understand. It consists of ten items that were graded using the «Likert scale» depending on the frequency of the statements included.

The questionnaire was also the procedure chosen to collect information on the topic from teachers. In this case it is semi-structured, and respondents were given the opportunity to provide their comments on most of the items as well as to select the options they considered most appropriate. The Likert scale technique, though used in some cases here too, is not the predominant one. Most of the items have to do with answering bi-polar questions or selecting options from a list of possible answers.

These two instruments employed were in the official language of the country where the students and teachers lived, and were filled in in that language as well. This was so in order that language did not interfere in the collection of the most accurate possible data as Spanish and English were in the vast majority of cases the mother tongue of respondents in Jaén and Newcastle schools, respectively, or they were quite fluent in them. Moreover, both of the questionnaires enabled students and teachers to remain anonymous in order to ensure the truest possible answers.

\subsection{Procedure}

In January 2007, I first visited the schools in Jaén offering ESO in order to ask the Headmaster or Headmistress for permission to carry out the research.

Thanks to a letter of introduction that the Director of my PhD Thesis, Dr. Antonio BuenoGonzález, had written about myself and about my intended research, I was cordially welcomed in all of them and none of them refused but one. Two schools could not participate because of time constraints. 
In many cases the Headmaster's or Headmistress' acceptance was not enough for this project having the green light and the Department of English had the last word, which sounds reasonable. On many occasions, in those first visits, I was allowed to look for any of the teachers of this department inside the school and convince them myself. Other times I had to go back to the school to meet them. Afterwards, I contacted them for a second time to ask the groups I could sample and agree on the day/s and time I would do it. Often, in any of these previous contacts we had I already gave them copies of their questionnaire, so some of them handed them back to me on the day I entered their class. However, I did not want to hurry teachers into their filling in, so I told them they could have until the end of February to do it. At that time I needed to go to the schools again to examine the course teaching contents. Thus, two birds could be caught with one stone.

In November 2007, I benefited from a postgraduate research stay at Newcastle University thanks to the kind invitation of Dr. Scott Windeatt. I contacted the schools in the Local Education Authority of Newcastle-upon-Tyne which offered the teaching of Key Stages 3 and 4. I could access teachers and classes in this city thanks to a letter of introduction that I drafted and that Dr. Windeatt slightly modified and signed. This letter ended up being essential as I was asked for it in all schools.

Unfortunately, I could not meet the Headmasters/Headmistresses or the Heads of the Departments of Modern Foreign Languages (MFLs) when I visited many of the schools, even if I tried to visit these institutions either at break or lunch time and I would not have minded waiting (I was told a formal appointment was necessary). The staff at their receptions suggested leaving the letter of introduction or emailing it to them so that they could pass the information to the Head of the Department of MFLs. Sadly, few of the schools where any of the MFL staff could not be met in person contacted me back, even if I tried twice in some cases. Probably, the fact that I could meet teachers of English face-to-face when I visited the schools in Jaén, together with the fact that Dr. Bueno González is very well-known in the teaching sector, especially in the English teaching one, of this small city are the reasons why a much higher percentage of Jaén institutions participated in this study.

It was agreed with the schools that were willing to help when in the following weeks they would be visited and which of their classes would be sampled. As happened in Jaén, a few teachers had filled in their questionnaire by those visits. The rest gave them back to me when I last visited the schools again in the second or third week of December 2007 with a view to examining their course contents.

Afterwards, in spring 2008, I made the analysis of this information gathered from students and teachers in Jaén and Newcastle schools.

\subsection{Data collection}

Instead of selecting some secondary schools in both cities at random, it was decided to try to implement the study in all of them, as they are not many. I opted for this so as to make the research as representative of each city as possible. In Jaén, luckily, $86.9 \%$ of high schools could be sampled. Thus, the data gathered can be argued to shed light accurately on the situation in the whole city concerning the CCI approach within the English classroom. On the contrary, the same cannot be said about the information obtained in Newcastle, as only $45 \%$ of its secondary schools participated in this piece of research. On the positive side, the data 
collected from this city could be argued to give a close depiction of what we wanted to find out since, as in Jaén, three types of schools and most areas of the city having a school (West Denton, Kenton, Gosforth, Fenham, Longbenton and Jesmond) are represented.

On the one hand, the students' questionnaires were handed in January 2007 in Jaén and at the end of November/beginning of December 2007 in Newcastle. Thus, they were answered in both cities after a similar number of school weeks since the start of the academic year. All pupils were told to focus on that period since the course began.

Students were not left alone when answering. I explained to them what the activity would be about and insisted that they should not reply to each of the items until I had read them aloud and had made some comments. With a view to helping them answer more accurately the first statement (the one about the teaching frequency of each of the CCIs), I read aloud the content that could be covered in the FL classroom in these levels if an approach like the LOGSE CCI one was to be followed (see table 1). This content is included in the guidelines for teaching these issues in ESO published by the Spanish Ministry of Education in 1992.

Table 1.: CCI content based on the LOGSE guidelines that could be covered in the ESO/8-11 year FL classroom

\begin{tabular}{|c|c|}
\hline $\begin{array}{l}\text { Peace education (Jares, 1992) } \\
\text { - Intercultural education } \\
\text { - Talking instead of fighting as the } \\
\text { way to bridge differences } \\
\text { - Comradeship, cooperation; NGOs, } \\
\text { world socio-economic injustice } \\
\text { - Respect for other young people (as } \\
\text { a way to avoid violence), bullying } \\
\text { - Peace and disarmament } \\
\text { - Friendship, love and family } \\
\text { - Different religions education }\end{array}$ & $\begin{array}{l}\quad \frac{\text { Moral and civic education }}{\text { (Puig Rovira, 1992) }} \\
\text { - Developing a sense of national and } \\
\text { global citizenship } \\
\text { - Democracy, the Universal } \\
\text { Declaration of Human Rights } \\
\text { - Being supportive, polite and tolerant } \\
\text { to other people's opinions and } \\
\text { conditions } \\
\text { - Following rules in society for a } \\
\text { happy coexistence } \\
\text { - Building one's own system of } \\
\text { values that does not threaten other } \\
\text { people's happiness }\end{array}$ \\
\hline $\begin{array}{l}\text { Environmental education (Jiménez } \\
\text { Armesto and Laliena Andreu, 1992) } \\
\text { - Ways to protect the environment } \\
\text { (recycling, renewal energies, saving } \\
\text { water and electricity...) } \\
\text { - Environmental problems affecting } \\
\text { the planet, climate change, } \\
\text { deforestation } \\
\text { - Animals, geographical phenomena } \\
\text { - Respect for the environment }\end{array}$ & $\begin{array}{l}\quad \text { Sex education (Nieda, 1992) } \\
\text { - Concepts of sexuality, relationship, } \\
\text { marriage, attraction and love } \\
\text { - Body changes during puberty } \\
\text { - Psychological differences between } \\
\text { boys and girls during adolescence } \\
\text { - Sexually transmitted illnesses, } \\
\text { contraception and abortion. To value } \\
\text { the importance of affection in sexual } \\
\text { relationships (for 3rd-4th year ESO } \\
\text { /Key Stage } 4 \text { students only) }\end{array}$ \\
\hline
\end{tabular}


Table 1.: CCI content based on the LOGSE guidelines that could be covered in the ESO/8-11 year FL classroom. (Cont.)

\begin{tabular}{|c|c|}
\hline $\begin{array}{l}\text { Gender education (Mañeru Méndez } \\
\text { and Rubio Herráez, 1992) } \\
\text { - Gender-based violence } \\
\text { - Gender equality in society (e.g. at } \\
\text { home, work and sport) } \\
\text { - Women's and men's rights in } \\
\text { different parts of the world } \\
\text { - Sexism in language }\end{array}$ & $\begin{array}{l}\text { Health education (Nieda, 1992) } \\
\text { - Healthy habits (e.g. eating healthy, } \\
\text { following the food pyramid, hygiene, } \\
\text { doing sports...) } \\
\text { - Common illnesses, injuries } \\
\text { - Health hazards } \\
\text { - Drugs }\end{array}$ \\
\hline $\begin{array}{l}\frac{\text { Road safety education }}{\text { (Ocio Simó, 1992) }} \\
\text { - Road safety signs and rules } \\
\text { - How to act in case of accident } \\
\text { - Directions } \\
\text { - Understanding the use of public } \\
\text { transport and using it politely }\end{array}$ & $\begin{array}{l}\quad \text { Consumer education } \\
\quad \text { (Álvarez Martín, 1992) } \\
\text { - Free time options } \\
\text { - Shopping, consumerism } \\
\text { - Advertising } \\
\text { - Staying at a hotel, eating out } \\
\text { - Kinds of housing to live in } \\
\text { - Learning about public services and } \\
\text { having a critical attitude towards } \\
\text { them }\end{array}$ \\
\hline
\end{tabular}

The questionnaire was usually administered in the FL class. I was sometimes offered to do it when students were in other classes, which I accepted for time reasons. During the approximately 25 minutes that it took me to get quantitative data from pupils, teachers were free to leave or stay in the classroom. When they opted for the second possibility they were asked not to condition the students' answers. Students were told that the activity was personal and that they should not give their opinion aloud, as this might lead the rest of the class to copy their answer. It was also made clear to them that the survey was anonymous and they were asked for their sincerity in answering.

On the other hand, teachers provided quantitative and qualitative information by means of their questionnaires, which they kept for some days. Those in Jaén had around a month to fill them in while the ones in Newcastle were asked to answer them in one or two weeks only. It does not seem the different amount of time that was given to teachers in both cities could have an effect on the results. It helps to confirm this idea the fact that some of the Jaén and Newcastle teachers to which copies had been handed in the first meetings (usually, so that they could approve of the research based on their content and on that of the student's questionnaire) gave them back as soon as the day their class was sampled and, apart from that, that the vast majority of them said it had not taken them more than an hour/an hour and a half to fill them in.

In addition, the questionnaire for Newcastle teachers was a bit shorter since a few of the items from the one administered in Jaén were deleted. I decided to do so because after handing them in Jaén I realised that they were unnecessary for achieving the objectives of my $\mathrm{PhD}$ Thesis. 


\subsection{Data analysis}

The analysis of the information that was collected was done by the «mean» in all cases. When some data could not be analysed because either the respondent did not provide an answer or it is unclear, this will be indicated in the figures below by means of the «N.A.» (not applicable) abbreviation.

\subsubsection{Student responses}

According to students surveyed in Jaén, moral and civic education was the most commonly dealt with in their English classroom CCI as $43.4 \%$ of them answered that it was taught either «always» or «often». The rest, around $46 \%$, responded either «few times» or «never» to the same question. It is very closely followed by environmental education, which was taught either «always» or «often» in the opinion of $43.3 \%$ of learners. Then, health and gender education come together on the list because in both cases $41.1 \%$ of students answered that they were covered either «always» or «often». Peace education is the next issue that was taught that often, namely $40.9 \%$ of respondents believed it. Consumer, road safety and sex education were by far the least commonly addressed CCIs from their point of view because only $20 \%$, $17 \%$ and $7.9 \%$ of them, respectively, went for any of these two options.

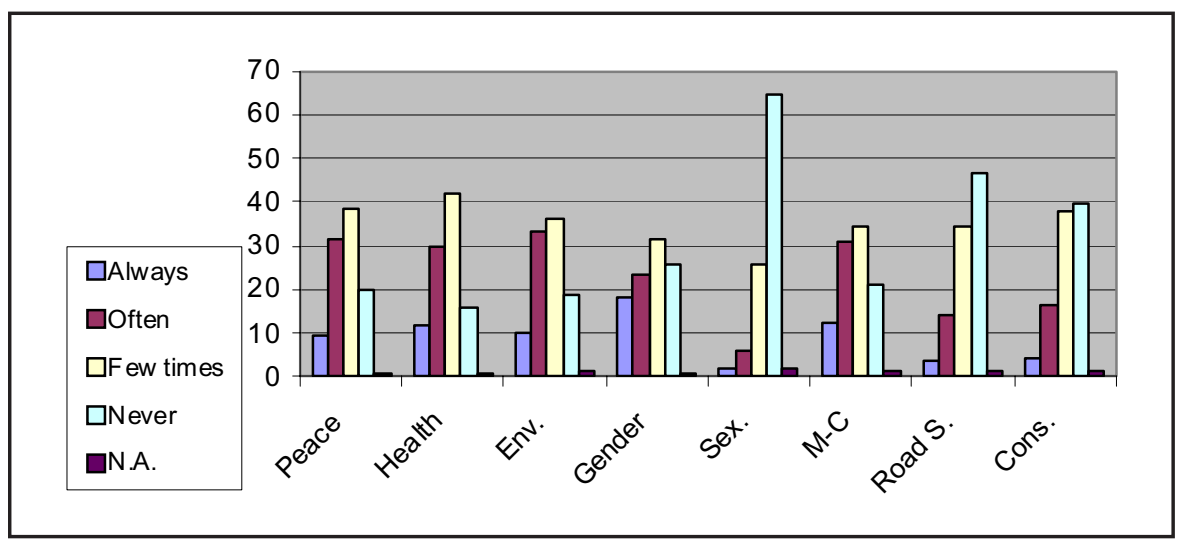

Figure 1: Frequency of CCI education in the English classes in Jaén schools according to students

On the other hand, for students sampled in Newcastle the CCI that was most commonly addressed in their FL classes was health education. 39.9\% of them answered that it was taught either «always» or «often». The boxes for these two kinds of frequency were ticked by $33 \%$, $30 \%$ and $26.9 \%$ of learners with regard to gender, environmental and peace education, respectively. Moral and civic education, in this case, was taught «always» or «often» in the FL classes only by $22 \%$ of teenagers (soon-to-be teenagers in very few situations). Consumer, sex and road 
safety education, though in different order, were also the least widely taught CCIs for them, as for Jaén students. $17 \%, 6.5 \%$ and $5.5 \%$ of them, respectively, chose any of the two positive answers concerning these three issues.

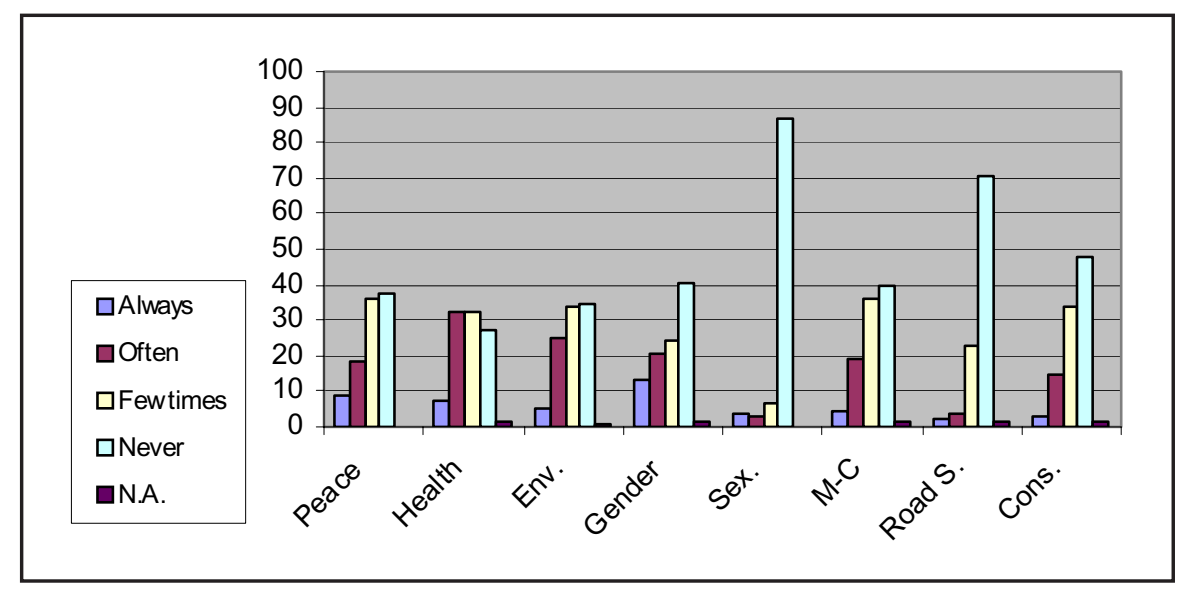

Figure 2: Frequency of CCI education in the FL classes in Newcastle schools according to students

As a way of knowing their general impression on their learning of content on the CCIs, they were asked if they thought they learnt something different from the target foreign language and culture and they were told to think particularly on the teaching of the issues they had just been surveyed about in the previous part of the questionnaire, that is to say, the CCIs. Learning cultural aspects of the target language can be regarded as learning peace education content (see table 1 above), therefore, as learning cross-curricular content. However, culture was included in the second statement of the questionnaire in case it conditioned their answers too much, as the FL culture is usually widely present in the published materials but it means only a part of the peace education content and a small amount of the CCI content that can be addressed in the FL classroom.

According to $37 \%$ of students in Jaén, something different from the foreign language and culture was learnt in their classes either «always» or «often», the latter being the most common answer. However, the majority of them, $43 \%$, thought that happened «few times» and around $18 \%$ believed that was never the case.

On this same topic, a lower percentage of students in Newcastle, namely $28 \%$, ticked the «always» or «often» boxes in favour of the «never» one, to a greater extent, and of not applicable answers, to a lesser extent. The percentage of «few times» replies given is practically the same than the percentage of those given in Jaén. 


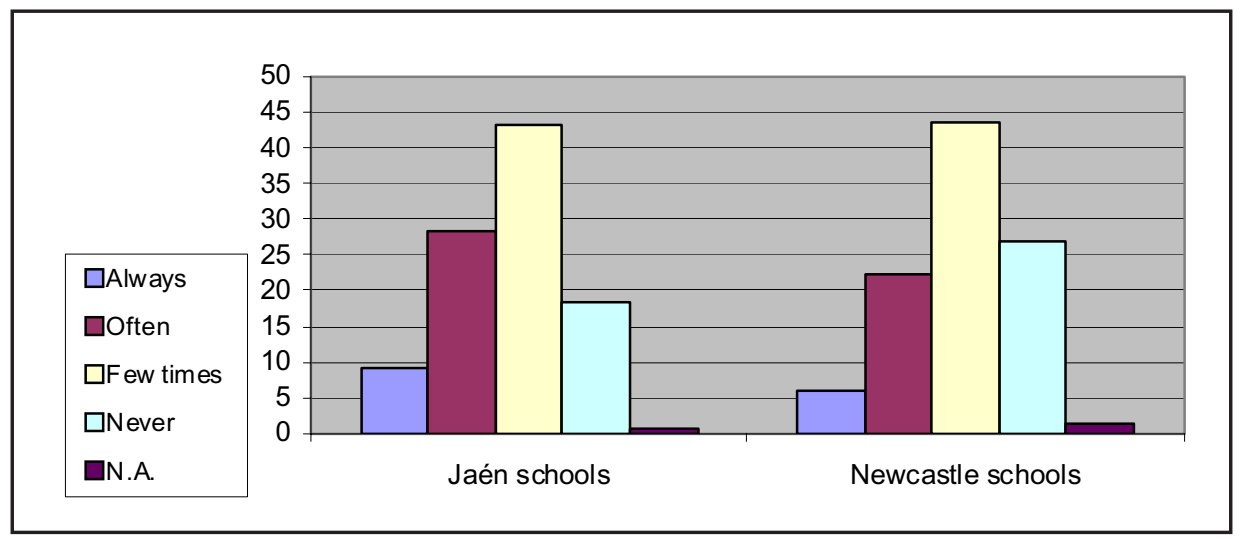

Figure 3: Learning something else apart from the foreign language and culture according to Jaén and Newcastle students

\subsubsection{Teacher responses}

The first key question to achieve the objectives of this paper that teachers were asked was whether they taught the LOGSE CCIs in their classes or not. The percentage of sampled teachers in Jaén and Newcastle that said they did, $85 \%$ and $83 \%$ respectively, is quite similar. Those who gave a negative reply did not need to answer the next questions in section B) of the survey.

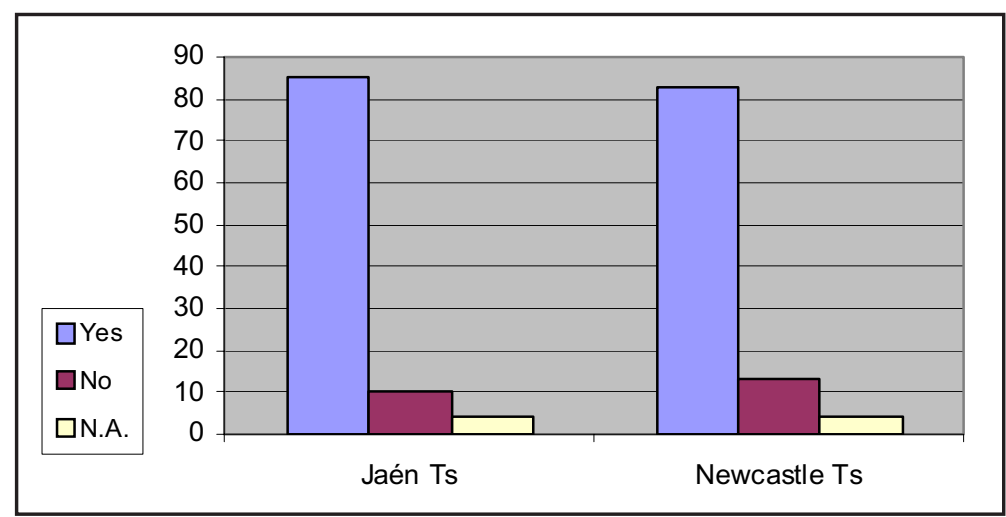

Figure 4: CCI teaching

Responses to the question about the percentage given to CCI teaching during the whole academic year show that none of them devoted more than $50 \%$ of the year to educating in them, with the exception of one teacher in Jaén. Most of them dedicated less than $25 \%$ and some between $25 \%$ and $50 \%$ of it to their teaching. The second option was chosen by a higher 
percentage of teachers in Jaén than in Newcastle, and the other way round concerning the first option.

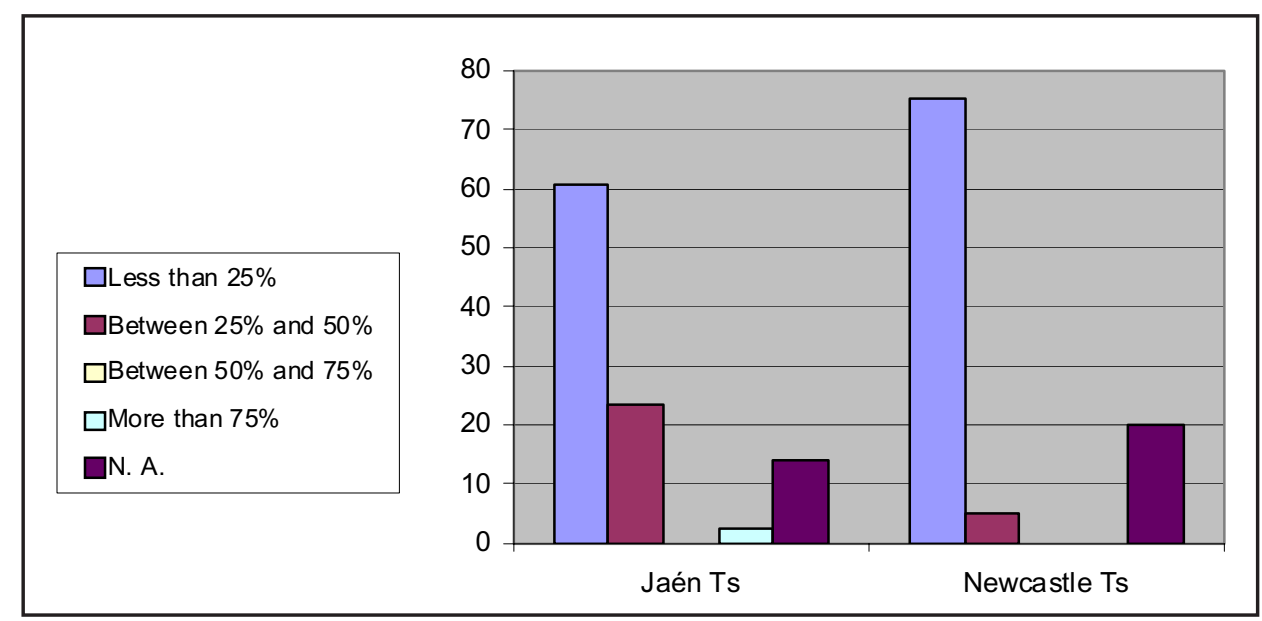

Figure 5: Percentage given to CCI teaching during the whole academic year

The majority of teachers, especially the Newcastle ones, approached some CCIs more than others. In contrast, the percentage of respondents who paid equal attention to all these issues is in Jaén twice the share of those in the British city who ticked the corresponding box.

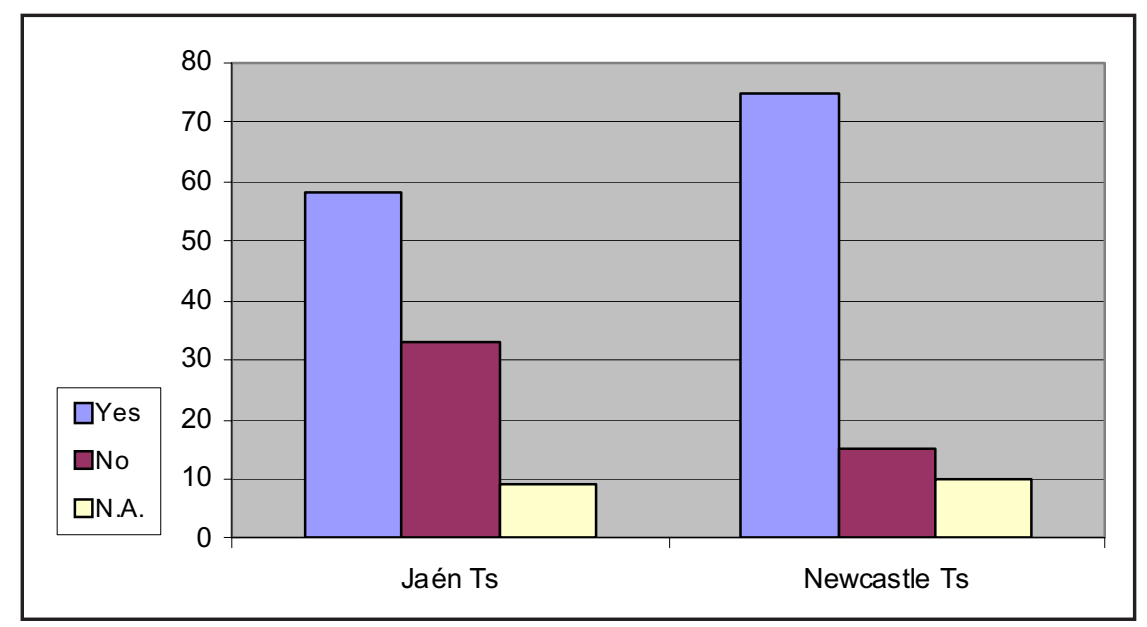

Figure 6: Approaching some CCIs more than others. 
There is not one or two CCIs in particular that were most commonly approached than the others by teachers in Jaén. However, there is a group of five of these issues (peace, health, environmental, gender, and moral and civic education) which can be clearly differentiated from the other three (consumer, road safety and sex education) as for the frequency with which they were addressed. On the other hand, more than half of the teachers that were sampled in Newcastle agreed on replying that they devoted more time to health or/and environmental education than to the other cross-curricular topics.

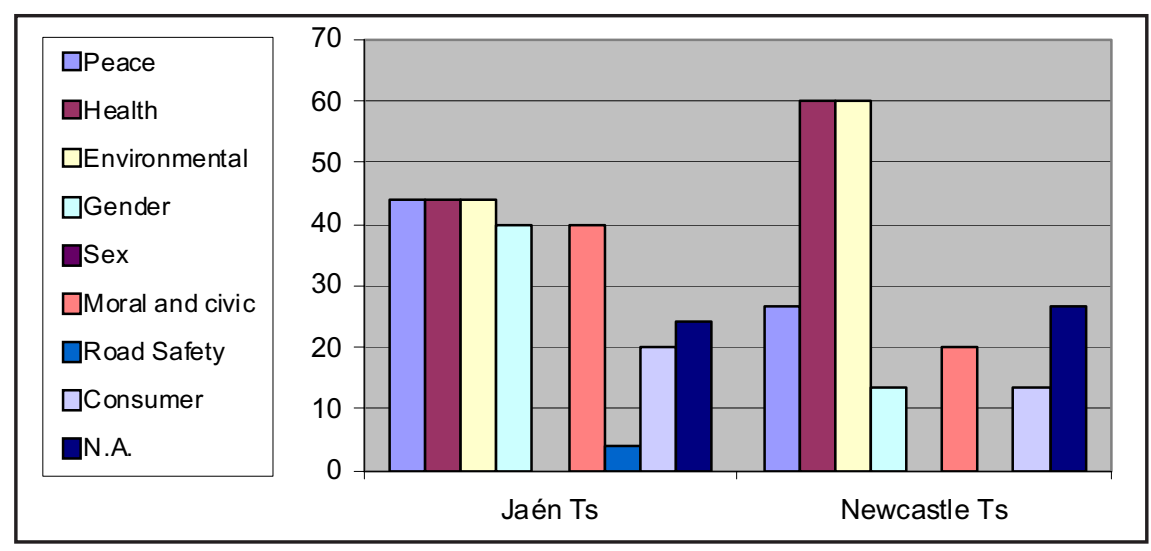

Figure 7.: CCIs that are most frequently approached

Results obtained from asking teachers in Jaén and Newcastle about the materials and resources they used for CCI teaching do not coincide. While the coursebook and the activity book, to a greater extent, and songs and ICT, to a lesser extent, were almost the only materials and resources used by the former with that purpose, up to six different ones were exploited by the latter, including authentic materials and films. Nevertheless, the most important difference between their answers is that while published materials were the main source of CCI education for the former, ICT was the most relied on resource among the latter when they introduced this kind of content in their classes. 


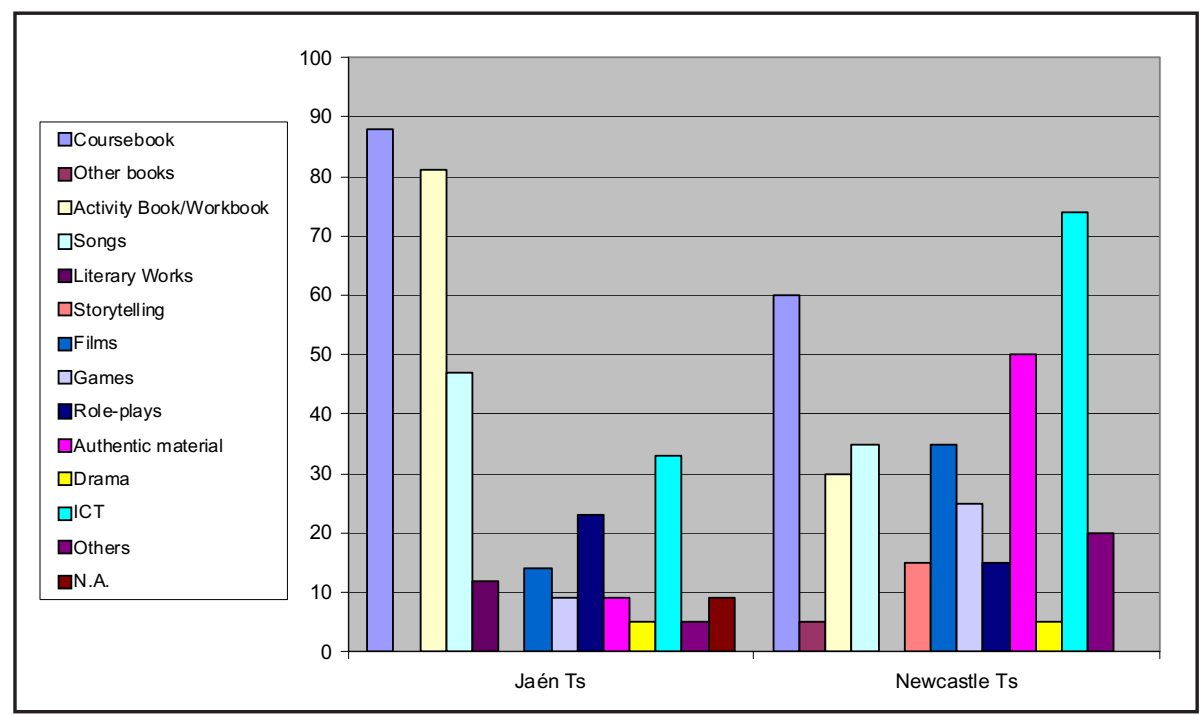

Figure 8.: Materials and resources used for CCI teaching

The last question in the teachers' survey providing crucial information to achieve the objectives of this piece of research has to do with CCI evaluation. The data gathered clearly shows that few teachers gave assessment on these topics any importance in the final qualification of the subject, especially the Newcastle ones (10\% as against $35 \%$ in the Spanish city). On the contrary, $12 \%$ of respondents in Jaén answered that they gave to their evaluation between $25 \%$ and $50 \%$ of the percentage of the FL subject mark.

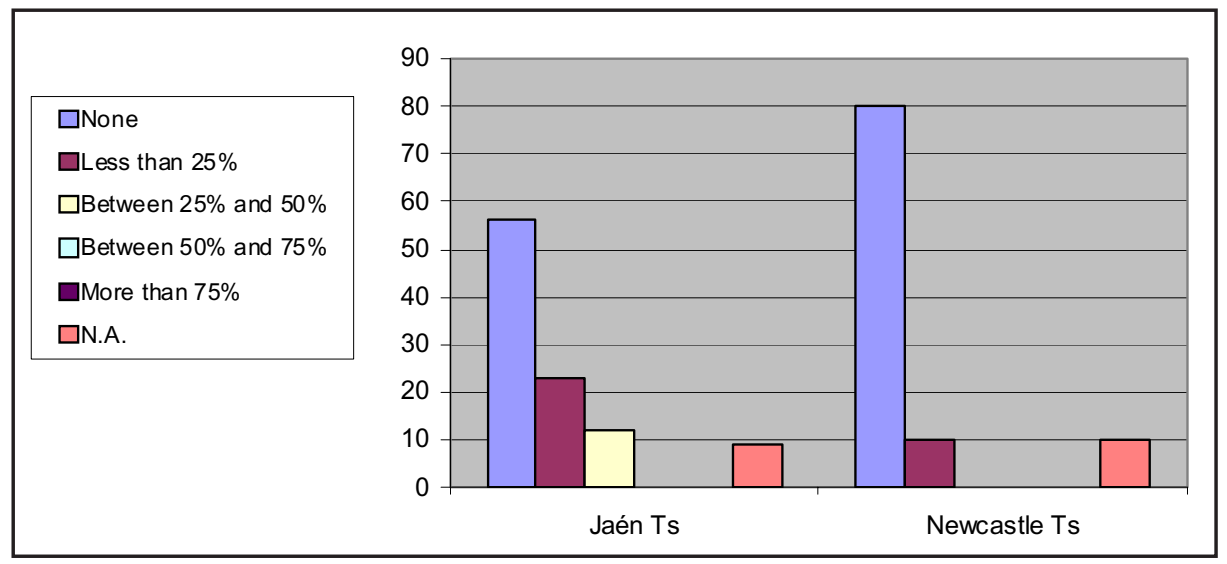

Figure 9: Percentage of the FL subject mark given to CCI evaluation. 


\section{Conclusions}

Objective 1. Five of the LOGSE cross-curricular topics, moral and civic, environmental, health, gender and peace education, are commonly addressed in the ESO English classrooms of Jaén according to around $40 \%$ of students sampled in this city. Contrarily, these issues, especially peace and moral and civic education, are not often addressed in the 8-11 year French or Spanish classes of Newcastle from the point of view of such a high percentage of respondents. Results also show that there is a group of three CCIs, consumer, road safety and sex education, that are not widely covered in the FL classes of both cities. Moreover, it can be concluded from student answers that this kind of content in general is more often covered in these subjects in Jaén than in Newcastle (see figure 2).

Objective 2. A very high percentage of FL teachers in these levels in the two cities deal with the CCIs. Most of them, especially the Newcastle ones, dedicate less than $25 \%$ of the whole academic year to teaching them and approach some more than others. Data analysed also sheds light on the issues that teachers cover more. While there is a group of five issues that obtain a similar proportion of Jaén teacher answers in this respect (the same five that are the most widely addressed for their learners), there are two - health and environmental education - to which the majority of teachers in Newcastle give priority over the rest (the same two issues together with gender education that are the most commonly addressed according to their students).

Objective 3. Coursebooks and activity books are the materials that are used with most groups in Jaén so as to educate in the CCIs. In contrast, the materials and resources that are employed in the majority of classes in Newcastle with this aim are ICT, coursebooks and authentic materials. Thus, it can be argued that computer technology is given a more important role for the teaching of these issues in the 8-11 year FL classes of the northern European city than in the ESO English classrooms of the southern European one that were sampled.

Objective 4. Evaluation on the CCIs barely takes part in the FL subject mark, especially in Newcastle, according to results. However, a small number of teachers in Jaén consider their assessment very important as they give it a very acceptable percentage of the final qualification. It should be mentioned that at the time this research was carried out year 9 and year 11 students in England were assessed externally and not by their teachers at the end of their courses.

To round off, the cross-curricular approach introduced by the LOGSE in Spain (above all the issues of peace and moral and civic education) is more often followed in the contexts under investigation of Jaén than of Newcastle, according to learners and teachers sampled. Therefore, a curriculum explicitly recommending the teaching of these topics in all subjects, like the LOGSE one, seems to favour their integration in the FL class more than another one not mentioning them and preferring content of moral and civic kind to be covered in specific subjects, like the 2000 National Curriculum for England. However, results obtained in Newcastle cannot be generalised to the whole city, as against those gathered in Jaén. Furthermore, data provided here should be combined with the objective analysis of the course contents. On the other hand, as new curricula have recently come into force in the two cities, it would be interesting to replicate this study in a few years, once they are fully applicable, to see if results obtained differ from the ones shown here. 


\section{REFERENCES}

Álvarez Martín, M ${ }^{a}$ N. (1992). Educación para el consumidor: transversales. Madrid: Ministerio de Educación y Ciencia.

Jares, X. R. (1992). Educación para la paz: transversales. Madrid: Ministerio de Educación y Ciencia.

Jiménez Armesto, M ${ }^{a}$ J. and Laliena Andreu, L. (1992). Educación ambiental: transversales. Madrid: Ministerio de Educación y Ciencia.

Mañeru Méndez, A. and Rubio Herráez, E. (1992). Educación para la igualdad de oportunidades: transversales. Madrid: Ministerio de Educación y Ciencia.

Nieda, J. (1992). Educación para la salud. Educación sexual: transversales. Madrid: Ministerio de Educación y Ciencia.

Nunan, D. (1992). Research Methods in Language Learning. Cambridge: Cambridge University Press.

Ocio Simó, E. S. (1992). Educación vial: transversales. Madrid: Ministerio de Educación y Ciencia.

Puig Rovira, J. Mª (1992). Educación moral y cívica: transversales. Madrid: Ministerio de Educación y Ciencia.

Real Decreto 1345/1991, de 6 de septiembre, por el que se establece el currículo de la Educación Secundaria Obligatoria. BOE n²20 de 13 de septiembre de 1991. Madrid: Ministerio de Educación y Ciencia.

National Curriculum Online 2009. Qualification and Curriculum Development Agency. 15 Oct. $2009<$ http://curriculum.qcda.gov.uk/>. 


\section{APPENDIX A}

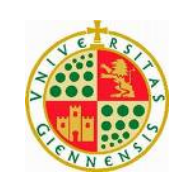

\section{STUDENT'S QUESTIONNAIRE ${ }^{1}$}

\section{A) Student's profile}

\begin{tabular}{|lcr|r|}
\hline Age: $12 \square \quad 13 \quad \square \quad 14 \quad \square \quad 15 \quad 16 \quad \square \quad 17 \quad \square$ \\
\hline Sex: $\quad$ Male $\square \quad$ Female $\square$ \\
\hline Year group: $\quad$ 8th $\square \quad$ 9th $\square \quad 10$ th $\square \quad 11$ th $\square$ \\
\hline
\end{tabular}

\section{B) Questionnaire}

State how often the circumstances mentioned below happen in your foreign language classroom.

1. The following issues are dealt with:

Peace
Health
Environment
Gender
Sex education
Moral and civic educ.
Road safety
Consumer education

Always Ofte

\section{Often}

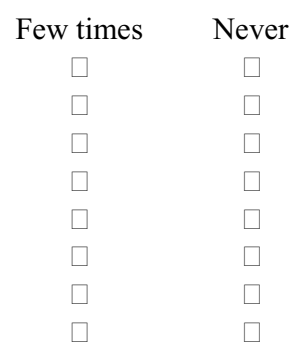

2. The following technology is exploited:

\begin{tabular}{|c|c|c|c|c|}
\hline \multicolumn{2}{|r|}{ Always } & Often & Few times & Never \\
\hline Radio-cassette player & $\square$ & $\square$ & $\square$ & $\square$ \\
\hline CD-player & $\square$ & $\square$ & $\square$ & $\square$ \\
\hline Television & $\square$ & $\square$ & $\square$ & $\square$ \\
\hline Video & $\square$ & $\square$ & $\square$ & $\square$ \\
\hline \multirow{2}{*}{ DVD-player } & $\square$ & $\square$ & $\square$ & $\square$ \\
\hline & Always & Often & Few times & Never \\
\hline PowerPoint & $\square$ & $\square$ & $\square$ & $\square$ \\
\hline Software & $\square$ & $\square$ & $\square$ & $\square$ \\
\hline The Web & $\square$ & $\square$ & $\square$ & $\square$ \\
\hline OHP & $\square$ & $\square$ & $\square$ & $\square$ \\
\hline Camera & $\square$ & $\square$ & $\square$ & $\square$ \\
\hline
\end{tabular}

1. This is a shortened version of the questionnaire learners in Newcastle filled in, which only differs from the one handed to Jaén students in the year group options given and in that it was in English, not in Spanish. 
Videocamera

Other

Please specify

3. Apart from the coursebook, the following materials or resources are used:
Always
Often
Few times
Never

Photocopies

Songs

Films

Other books

Newspaper articles

4. You learn something else apart from the foreign language and culture.
Always
Often
Few times
Never

5. You have your classes in the ICT room.

Always $\square \quad$ Often $\square \quad$ Few times $\square \quad$ Never

6. You can access a library that has books in the foreign language you are learning and that deal with any of the issues in 1 .
Always
Often
Few times
Never

7. You work in pairs, groups or teams.

Always $\square \quad$ Often $\square \quad$ Few times $\square \quad$ Never

8. You can comfortably discuss and give your point of view about something with your teacher.

Always $\square \quad$ Often $\square \quad$ Few times $\square \quad$ Never

9. You can choose what you want to learn about the issues in 1.

Always $\square \quad$ Often $\square \quad$ Few times $\square \quad$ Never

10. You are taught to be critical, open-minded and to respect other people's opinions.

Always $\square \quad$ Often $\square \quad$ Few times $\square \quad$ Never 


\section{APPENDIX B}

\section{FOREIGN LANGUAGE TEACHER'S QUESTIONNAIRE ${ }^{2}$}

\section{Instructions}

Please, fill in this anonymous questionnaire carefully and as accurately as possible.

Put a cross next to the appropriate answer in the box provided.

Notice that it is possible to give more than an answer to some of the questions.

Add a comment to your answer, when you are given this opportunity, if you consider it necessary.

\section{A) General considerations about foreign language teaching}

1. How often do you keep to the subject syllabus in your classes?
Always
Often
Few times
Never
Comments

\section{B) Cross-curricular issues}

2. What do you understand by "cross-curricular issues"?

3. List those that you can remember

4. Do you think that it is possible to learn about cross-curricular issues at the same time as about a foreign culture and language? (From now onwards, by "cross-curricular issues" we will be meaning those in question 6.)

Yes $\square \quad$ No $\square$

Why?

2. This is a shortened version of the questionnaire teachers in Newcastle filled in. All the items it includes were also included in the one handed to their colleagues in Jaén. The latter was composed of a few more items, which are not relevant for this study. Apart from this, the only difference between the two questionnaires is the language in which they are written. 
5. Do you address cross-curricular issues in your classes?

Yes $\square \quad$ No $\square$

Why?

If you do not, skip questions 6-16.

6. What percentage do you devote to addressing cross-curricular issues in your classes during the whole academic year, approximately? (If you do not deal with some of them, do not cross any of the options on their right)

\begin{tabular}{|c|c|c|c|c|}
\hline & $-25 \%$ & $25 \%-50 \%$ & $50 \%-75 \%$ & $+75 \%$ \\
\hline All in general & $\square$ & $\square$ & $\square$ & $\square$ \\
\hline Peace & $\square$ & $\square$ & $\square$ & $\square$ \\
\hline Health & $\square$ & $\square$ & $\square$ & $\square$ \\
\hline Environment & $\square$ & $\square$ & $\square$ & $\square$ Gender \\
\hline$\square$ & $\square$ & $\square$ & & \\
\hline Sex education & $\square$ & $\square$ & $\square$ & $\square$ \\
\hline Moral and civic ed. & $\square$ & $\square$ & $\square$ & $\square$ \\
\hline Road safety & $\square$ & $\square$ & $\square$ & $\square$ \\
\hline Consumer education & $\square$ & $\square$ & $\square$ & $\square$ \\
\hline
\end{tabular}

7. Do you approach some cross-curricular issues more than others?

Yes $\quad \square$ Which ones?

No

8. Do you select contents and objectives on cross-curricular teaching when making the lesson planning for the course?

Yes $\square \quad$ No

I do not make the lesson planning for the course

Comments

9. Do you meet teachers of other subjects when making the lesson planning for the course in order to organise together the teaching of this kind of issues in each of the curriculum areas?

Yes $\square \quad$ No $\square$

I do not make the lesson planning for the course

Comments

10. Have you created a resource pack for cross-curricular teaching purposes?

Yes $\square \quad$ No

Comments

11. What materials and resources do you use to deal with cross-curricular issues?

(Mark more than one box with a cross if necessary)

Songs

Technology

Activity book/workbook

Films

Authentic materials 
Literary works

Drama

Others
Games $\quad \square \quad$ Storytelling

Role-plays

Please specify

12. What percentage of the subject mark do you give to the evaluation of cross-curricular issues?

None

Less than $25 \%$

Between $25 \%$ and $50 \%$

Between $50 \%$ and $75 \%$

More than $75 \%$

13. What cross-curricular contents do you work more on?

Conceptual

Procedural

Attitudinal

All in the same way

14. In case you assess cross-curricular issues, what instruments do you use to do so? (Mark more than one box with a cross if necessary)

Tests

Self-checks

Evaluation charts

Others

Please specify

\section{C) Technology}

15. If you use some of the technology listed below in order to address cross-curricular issues, indicate how frequently you do so.

(Mark more than one box with a cross if necessary)

$\begin{array}{lcccc} & \text { Always } & \text { Often } & \text { Few times } & \text { Never } \\ \text { Radio-cassette player } & \square & \square & \square & \square \\ \text { CD-player } & \square & \square & \square & \square \\ \text { Television } & \square & \square & \square & \square \\ \text { Video } & \square & \square & \square & \square \\ \text { DVD-player } & \square & \square & \square & \square \\ \text { PowerPoint } & \square & \square & \square & \square \\ \text { Software } & \square & \square & \square & \square \\ \text { The Web } & \square & \square & \square & \square \\ \text { OHP } & \square & \square & \square & \square \\ \text { Camera } & \square & \square & \square & \square \\ \text { Videocamera } & \square & \square & \square & \square \\ \text { Other } & \square & \square & \square & \square \\ \text { Please specify } & \square & \square & \square & \square\end{array}$


16. Have you surfed the Internet to find information and/or materials on cross-curricular teaching for your classes?

Yes $\square \quad$ No

Comments

\section{D) Teacher's profile}

\begin{tabular}{|lll|}
\hline Age: $\quad 20-30 \quad \square \quad 30-40 \quad \square \quad 40-50 \quad \square \quad 50-60 \quad \square \quad 60+\square$ \\
\hline Sex: M $\square \quad$ F $\square$ & \\
\hline Type of institution you work at: & State-maintained \\
Publicly funded with a religious ethos & $\square \quad$ Independent $\quad \square$ \\
\hline
\end{tabular}

17. How many years have you been in the foreign language teaching profession?

Less than $5 \quad \square \quad$ Between 5 and $10 \quad \square \quad$ Between 10 and 20

Between 20 and $30 \quad \square \quad$ Between 30 and $40 \quad \square \quad$ More than 40

18. Do you think that you have been sufficiently trained to deal with cross-curricular issues?

Yes $\square \quad$ No

Comments 